УДК 338.43:504.064

O.О. Вовк, д-р техн. наук, проф. ORCID 0000-0002-7531-9847

C.В. Зайченко, д-р техн. наук, проф. ORCID 0000-0002-8446-5408

С.П. Чвертко, канд. техн. наук, доц.

М.В. Шевченко, канд. техн. наук, доц.

А.С. Пірумов, канд. техн. наук, доц.

О.Й. Радецька, магістрант

Національний технічний університет України «Київський політехнічний інститут імені Ігоря Сікорського»

\title{
АНАЛІЗ АВАРІЙ НА МАГІСТРАЛЬНИХ ТРУБОПРОВОДАХ ЗА ПЕРІОД 2005 - 2015 РР.
}

Трубопровідний транспорт широко застосовують для транспортування рідких речовин на великі відстані. Однак нерідко на трубопроводах виникають аварії внаслідок причин технологічного, технічного та суб'єктивного характеру, які призводять до забруднення значних території, пошкодження майна та навіть людських жертв. У статті проаналізовано аварії на магістральних трубопроводах в Украӥні $i$ США за період 2005 - 2015 рр. Встановлено, щчо аварії нерідко стають наслідком негативних прочесів, які відбуваються в трубопроводі внаслідок дії експлуатаційних факторів, таких як корозія, старіння металу, механічні навантаження. Поряд з циим нерідко аварії вникають на ділянках трубопроводів, які в силу різного роду причин, у тому числі, законодавчого характеру, не були достатньою мірою охоплені контролем та інспекцією. Встановлено, щуо моніторинг технічного стану трубопроводів є ефективним засобом запобігання аваріям або зменшення їх впливу на довкілля. Однак його проведення, окрім економічних факторів, обмежене через особливості роботи сучасних засобів вимірювання.

Ключові слова: магістральний трубопровід, аварія, причина аварії, моніторинг технічного стану

Вступ

Транспортування рідких речовин за допомогою трубопроводів є одним із широко вживаних у світі засобів для їх доставки від виробника до споживачів, особливо коли відстань між ними є значною. Згідно Закону України «Про трубопровідний транспорт» магістральний трубопровід $є$ технологічним комплексом, який функціонує як єдина система і до якого входить окремий трубопровід з усіма об'єктами і спорудами, зв'язаними з ним єдиним технологічним процесом, або кілька трубопроводів, якими здійснюються транзитні, міждержавні, міжрегіональні поставки продуктів транспортування споживачам [1]. В Україні трубопровідний транспорт використовують для перекачування нафти, нафтопродуктів, газу та аміаку. У порівнянні з іншими видами транспорту вони більш практичні та економічно доцільні для транспортування великих обсягів, однак привносять фактори небезпеки. Зокрема, існує ризик пошкодження трубопроводів, що може призвести до екологічного забруднення значних територій навколо нього. Нафтопродукти накопичуються в грунтових водах, системах каналізації, річках, озерах, колодязях та інших резервуарах природного і штучного походження. Як наслідок, все більші об'єми води $є$ непридатними для вживання, відбувається миттєва загибель живих організмів та повільна деградація флори. При аварії на газопроводі чи нафтопроводі в атмосферу потрапляє метан та його гомологи, вуглекислий газ та пари нафти, які впливають на центральну нервову систему, органи дихання тварин та людей, крім цього підвищується парниковий ефект.

Метою даного дослідження $є$ аналіз аварій на магістральних трубопроводах за період 2005 2015 рр. та їхніх причин, а також визначення можливих підходів до запобігання створенню аварійних ситуацій.

Аналіз причин аварій магістральних трубопроводів

За статистичними даними Державної служби України з надзвичайних ситуацій за період 2005 - 2015 pp. зафіксовано 34 аварії, з яких: на нафтопроводі - 13, на газопроводі - 14, на продуктопроводі - 6, на аміакопроводі - 1 [2]. Розподіл аварій в Україні за 2005 - 2015 рр за видами магістральних трубопроводів подано на рис. 1, а за областями країни - на рис. 2.

(C) О.О. Вовк, С.В. Зайченко, С.П. Чвертко, М.В. Шевченко, А.Є. Пірумов, О.Й. Радецька, 2017 


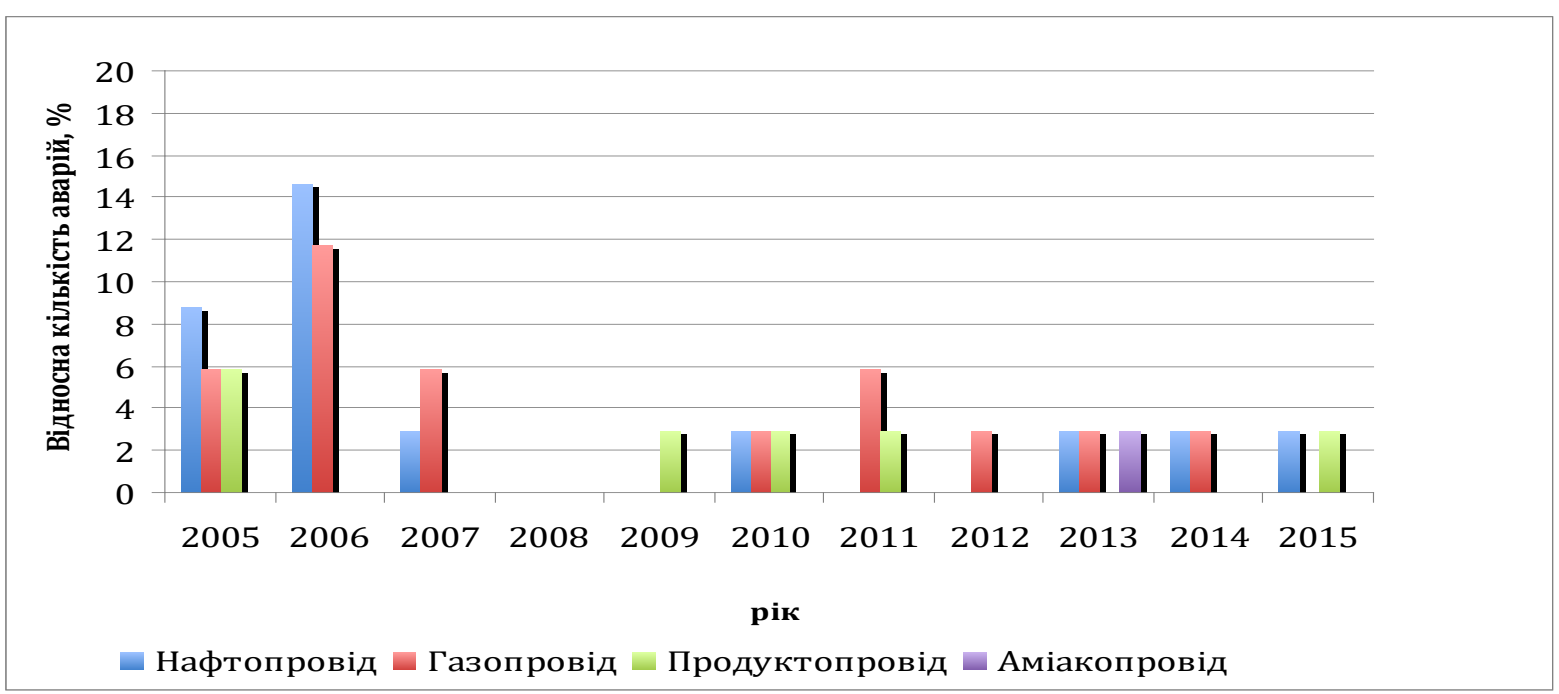

Рисунок 1 - Кількість аварій в Україні на магістральних трубопроводах у 2005 - 2015 рр.

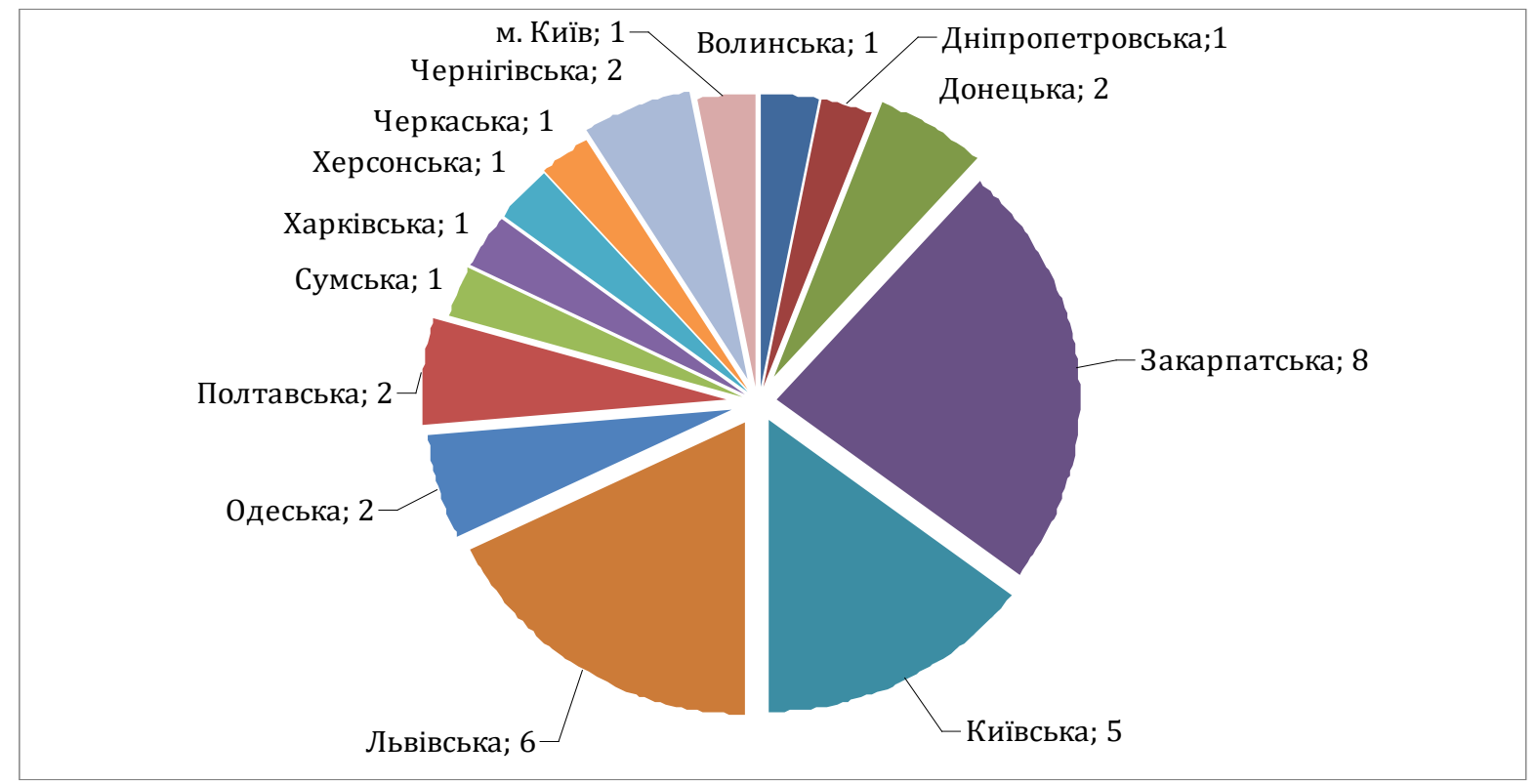

Рисунок 2. - Розподіл аварій по областям України у 2005 - 2015 рр.

Серед основних причин аварій, зокрема, виділено:

1. розгерметизацію трубопроводу внаслідок несанкціонованого врізання;

2. зношення трубопроводу (корозія);

3. порушення правил проведення земляних робіт;

4. зловмисне механічне пошкодження;

5. просідання грунту.

6.

Розглянемо аварії, які мали найбільший вплив на навколишнє середовище.

У 2013 р. поблизу с. Руське, Мукачівського району було виявлено маслянисту плівку на водній поверхні каналу "Полуй", яка виникла внаслідок витоку нафтопродуктів після несанкціонованого врізання невідомими зловмисниками на відстані 100 м від каналу. За результатами лабораторних гідрохімічних аналізів поверхневих вод вміст нафтопродуктів перевищував гранично допустиму концентрацію у 15 разів. Для запобігання поширення нафтопродукту вниз за течією каналу було встановлено бонові загородження, споруджено гідрозатвор, у місці аварії поверхневі води та грунт оброблено сорбентом "Еконадін".

Інша аварія в Закарпатській області сталася в 2014 р. поблизу с. Бенедиківці. 3 гілки магістрального нафтопроводу "Дружба" на магістралі "Броди Держкордон" діаметром 700 мм виявлено витік нафти за 
межі охоронної зони, внаслідок чого утворилася масляниста пляма на площі близько 0,7 га (7000 м²). Витік нафтопродукту було зупинено та проведено роботи з очищення території (відкачування нафтопродуктів та вивезення забрудненого шару грунту).

У 2015 p. в Закарпатській області відбулася розгерметизація продуктопроводу ДП "Прикарпатзахідтранс", внаслідок чого у руслі річки Уж в районі с. Ворочевого виявили забруднення

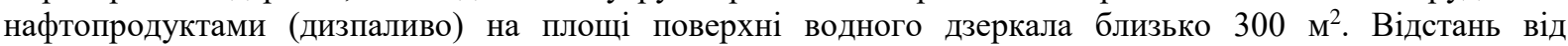
прокладання продуктопроводу до русла річки Уж становить 1,5 кілометра. 3 метою захисту водозабору міста Ужгород від потрапляння нафтопропродуктів поблизу с. Кам'яниці було встановлено бонові загорожі. Причиною аварії була несанкціонована врізка у продуктопровід.

Звернемо увагу, що більшість факторів, які найчастіше ставали причинами аварій, неможливо передбачити при проектуванні трубопроводу. Зокрема, сучасні методики дозволяють врахувати фактори корозії та несприятливих змін, які відбуваються в металі труб у ході експлуатації (так званого, старіння металу), а також частково - вплив зсувів грунту, в той час як фактори суб'єктивного характеру залишаються поза увагою під час проектування.

Слід також зазначити, що найбільшою загрозою для магістральних трубопроводів на даний час в Україні є ситуація в зоні проведення антитерористичної операції на території Донецької та Луганської областей. 3 матеріалів Національної акціонерної компанії “Нафтогаз України” до Національної доповіді “Про стан техногенної та природної безпеки в Україні у 2016 році” за весь період в зоні АТО було виявлено 2504 пошкоджень розподільних газопроводів, крім цього інформація щодо ситуації на непідконтрольних територіях практично відсутня [3].

У світі ситуація із трубопроводами також є складною. Найбільша кількість аварій спостерігається в Сполучених Штатах Америки. Загальна кількість аварій трубопроводів за вказаний період склала 309 (рис. 3) [4], що майже в 10 разів перевищує дані по Україні. Кількість аварій на рік становила від 15 у 2007 році до 46 у 2012, в той час як в Україні найбільша кількість аварій на рік становила 3 (у 2007, 2010 та 2013 роках), а 2008 охарактеризувався відсутністю зафіксованих держслужбами країни аварій.

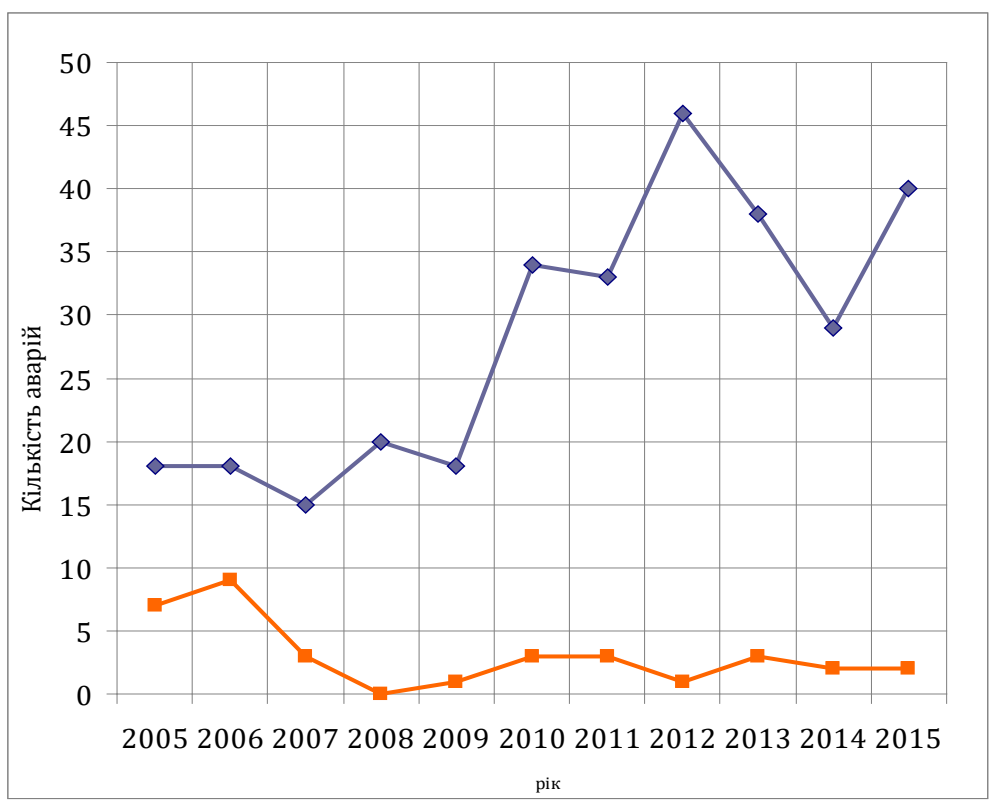

Рисунок 3 - Кількість аварій в США (синя лінія) та в Україні (оранжева лінія) за 2005 - 2015 рp.

Аварії на газо- і нафтопроводах в США - не рідкість, багато з них призводять і до людських жертв [5, 6]. Одна із таких катастроф сталася 10 вересня 2010 року в м. Сан-Бруно, штат Каліфорнія, де відбувся потужний вибух сталевого газопроводу діаметром 76 см. Вибух залишив після себе кратер глибиною до 12 метрів, діаметром 51 м. Вісім осіб загинуло, понад п’ятдесят було поранено. Висота полум'я сягала 90 м, очевидці повідомляли про вогняну кулю і стіну вогню заввишки 300 м.

Геологічна служба США зареєструвала результат ударної хвилі еквівалентний землетрусу в 1,1 бал за шкалою Ріхтера. До ліквідації пожежі було залучено понад 200 пожежників - сильний вітер роздував полум'я, ускладнюючи боротьбу з вогнем. У результаті вибуху і подальшої пожежі було пошкоджено 35 будинків, три з них були визнані непридатними для проживання.

На загальну довжину всіх трубопроводів Америки - 2,5 млн км, щорічно припадає сотні витоків $і$ розривів, ціною яких стають в окремих випадках і людські життя. 31986 року, при аваріях на трубопроводах вже загинуло більше 500 осіб, а постраждало понад 4000. По мірі старіння трубопровідних 


\section{ISSN 1813-5420 (Print). Енергетика: економіка, технології, екологія. 2017. № 4}

систем, ризик аварій на цих лініях буде тільки збільшуватися. Але більшості з них можна було б уникнути - при належному контролі з боку уряду і посиленню заходів безпеки в галузі.

Серед основних причин аварій називають корозію обладнання, незадовільну якість зварних швів і навіть стихійні лиха. Так, у 2012 році трубопроводи в штаті Нью-Джерсі піддалися атаці урагану "Сенді", що призвело до виникнення понад 1600 випадків розгерметизації трубопроводу.

Серйозною причиною виходу трубопроводів з ладу є корозія. Сталь, яка знаходиться у взаємодії 3 активними середовищами, такими як нафта чи газ - поступово деградує. На частку корозійних процесів припадає від 15 до 20 відсотків усіх повідомлень про "серйозні аварії", які призводять до загибелі людей або завдають серйозної шкоди майну.

Старіння металу трубопроводу (процес, який також призводить до негативних змін структури та властивостей матеріалу) також називають серед основних причин аварій. Більше половини трубопроводів в США побудовані більше п'ятдесяти років тому. Наприклад, у 2011 році, в місті Аллентаун вибухнув газопровід. Загинуло 5 людей, було знищено майже п'ятдесят будинків. Причиною було перевищення терміну експлуатації - газопровід було виготовлено з чавунних труб у 1928 році. Слід зазначити, що проблема вичерпання ресурсу роботи магістральних трубопроводів внаслідок тривалої експлуатації актуальна і для України.

У США основну частину державного контролю за функціонуванням нафтопроводів і газопроводів покладено на невелике агентство в складі Департаменту транспорту "Pipelines and Hazardous Materials Safety Administration" (Управління з безпеки трубопроводів і небезпечних матеріалів), скорочено PHMSA.

За даними агентства лише 7 \% трубопроводів передачі природного газу і 44 \% всіх небезпечних ліній передачі рідких нафтопродуктів відповідають жорстким критеріям перевірки і регулярно підлягають перевірці. Усі інші ділянки трубопроводів проходять контроль набагато рідше. Така ситуація склалась внаслідок того, що більшість федеральних законів про безпеку трубопроводів було прийнято у 60-ті і 70ті роки, у той самий час було встановлено стандарти безпеки для новозбудованих ліній.

Однак на трубопроводи, побудовані раніше 60 -х років, дані правила не поширювалися, до того ж (навіть для США) привести ці трубопроводи до єдиного стандарту безпеки неможливо. Саме до таких об'єктів належав газопровід, який вибухнув в місті Сан-Бруно. Ділянка, на якій лопнув трубопровід вздовж дефектного шва, як показало розслідування, ніколи не проходила випробувань підвищеним тиском. Але парадокс у тому, що, оскільки він був встановлений в 1956 році, його власник і не зобов'язаний був проводити таке тестування.

Пізніше, в 1990-х роках, були прийняті додаткові акти, і сьогодні PHMSA набирає персонал для тестування старих трубопроводів у зоні ризику. Однак багато старих газопроводів в сільській місцевості й досі не можуть бути охоплені інспекцією, а внаслідок величезної протяжності трубопроводів нафти і газу в Сполучених Штатах, PHMSA не вистачає ресурсів для ефективного моніторингу

Іншим елементом ризику трубопроводів є тимчасові і технічні лінії, наприклад магістралі, що з'єднують свердловини на родовищах. До них взагалі не застосовують жодні стандарти регулювання, оскільки багато з цих ліній працюють при дуже низьких тисках і знаходяться у віддалених районах. Тому урядові агенти не можуть зібрати об’єктивні дані про розриви й протікання, а також про те, чи дотримуються взагалі яких-небудь стандартів щодо характеристик зварних швів та глибини залягання трубопроводу.

Одним із шляхів вирішення такої ситуації є установка запірної арматури 3 автоматичним дистанційним управлінням, яка може швидко зупинити подачу газу або нафти в разі аварії.

У липні 2010 року, в результаті прориву нафтопроводу, в р. Каламазу витекло близько мільйона галонів сирої нафти. Операторам трубопроводу знадобилося майже 17 годин для того, щоб знайти і вручну перекрити місце розриву. Використання автоматичної арматури дозволило б значно скоротити цей час, а отже - зменшити масштаб екологічного забруднення місцевості.

Існує й інша технологія запобігання витокам i розривам. Для діагностики технічного стану трубопроводів в нафтогазовій промисловості використовують роботів - трубопровідні контрольновимірювальні пристрої під назвою "Smart Pig” (рис. 4).

Такі пристрої розміщують в газопроводі і вони рухаються в трубі, визначаючи деформації труб і пошкодження металу. Однак не кожен газопровід має відповідний діаметр для використання подібного пристрою [7]. Відомі також системи із датчиками для локального вимірювання механічних напружень у трубопроводах, які придатні до використання незалежно від діаметру трубопроводу [8]. Однак в обох випадках для регулярної діагностики потрібен частковий демонтаж конструкції. 


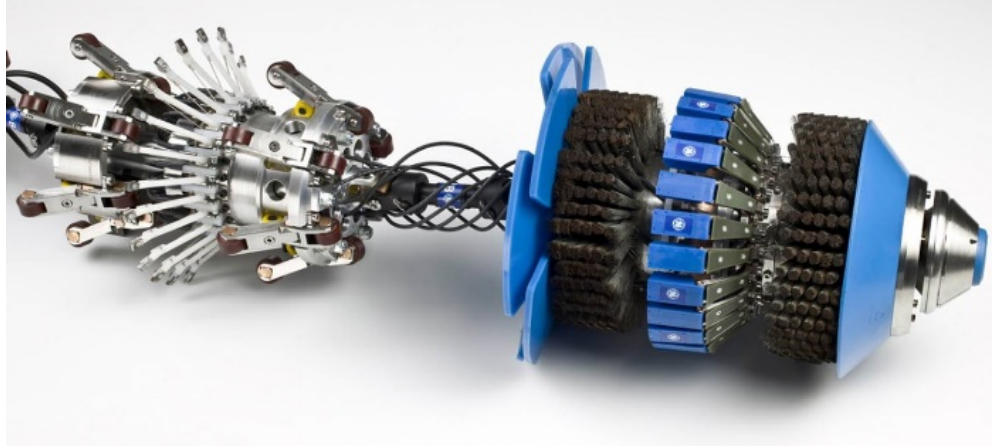

Рисунок 4 - Трубопровідний контрольно-вимірювальний пристрій “Smart Pig”

\section{Висновки}

1. Аварії на трубопроводах призводять до забруднення значних площ. Фактори, які спричиняють аварії, можна розділити на такі, що вносять на стадії проектування (неправильний вибір матеріалу, технології виготовлення, неврахування умов експлуатації), виготовлення (порушення технології, використання матеріалів незадовільної якості, недостатня увага контрольним заходам) та експлуатації (корозія, зовнішні механічні дії, старіння металу). В Україні серед причин аварій розповсюдженим $\epsilon$ суб'єктивний фактор, пов'язаний із недбалим ставленням до трубопроводу або порушенням вимог до його експлуатації.

2. Діагностика і моніторинг технічного стану трубопроводів дозволяє уникнути настання аварійних ситуацій і підвищити екологічну безпеку трубопровідного транспорту. Однак навіть найсучасніші засоби і методи діагностики й моніторингу мають певні обмеження, а в деяких випадках інспекція трубопроводів $\epsilon$ необов'язковою згідно вимог чинного законодавства.

3. Попередити аварійні ситуації на трубопроводах можливо за рахунок впровадження ефективних методик контролю та інспекції на всіх стадіях життєвого циклу конструкції. Актуальною на сьогодні $є$ розробка методик та засобів діагностики і моніторингу технічного стану магістральних трубопроводів. Зокрема, корисним буде визначення узагальнених вимог до проведення інспекції та критеріїв оцінювання, які були б придатними до застосування без обмежень технічного характеру.

\section{Список використаної літератури}

1. Закон України “Про трубопровідний транспорт” № 192/96 [Електронний ресурс]: прийнятий Верховною Радою України 15 травня 1996 р., зі змінами від 28.12.2015. - Київ. - Режим доступу: http://zakon2.rada.gov.ua/laws/show/192/96-вр.

2. Державна служба України з надзвичайних ситуацій [Електронний ресурс]. - 2016. - Режим доступу до ресурсу: http://www.dsns.gov.ua.

3. Матеріали Національної акціонерної компанії “Нафтогаз України” до Національної доповіді “Про стан техногенної та природної безпеки в Україні у 2016 році”.

4. List of pipeline accidents in the United States in the 21 st century [Електронний pecypc] // Wikipedia. 2017. - - Режим доступу до ресурсу: https://en.wikipedia.org/wiki/List_of_pipeline_accidents_in_the_United_States_in_the_21st_century\#2005.

5. Papadakis G. A. Review of transmission pipeline accidents involving hazardous substances / G. A. Papadakis. // European Communities. - 1999. - c. 64.

6. Paul W. Parfomak DOT’s Federal Pipeline Safety Program: Background and Key Issues for Congress / Paul W. Parfomak. // Congressional Research Service. - 2016. - c. 32.

7. Smart 'pigs' that sniff out trouble down the pipe [Електронний ресурс] // GE Reports. - 2014. - Режим доступу до ресурсу: https://gereports.ca/smart-pigs-that-sniff-out-trouble-down-the-pipe/\#.

8. A. Pirumov, M. Shevchenko, A. Minakov, S. Minakov, Ye. Chvertko Application of Reverse Magnetization Method of Evaluating Stresses in Welded Structures / Journal of Materials Science and Technology (Bulgary) 2015, Vol. 23, No. 4, pp. 295-302 


\section{ISSN 1813-5420 (Print). Енергетика: економіка, технології, екологія. 2017. № 4}

Main pipelines are widely used for transporting of liquid products on long distances. Unfortunately pipeline operating is related to a number of factors - technological, technical, subjective - which may cause accidents which, in turn, lead to pollution of wide territories, property damage and even casualties. The paper gives analysis of accidents on main pipelines in Ukraine and USA during the period of 2005 - 2015. It was determined that accidents often appear to be a result of negative processes in pipeline material during the structure operation, such as corrosion, ageing, mechanical loads and overloads, for example due to ground shifting. Also accidents tend to happen on pipelines which were not properly controlled and inspected. In addition, both Ukraine and USA have a number of old pipelines - those which estimated operation time has already finished. As a main conclusion it should be mentioned that up-to-date methods and means of monitoring of technical state of pipelines are essential for development and application.

Key words: main pipeline, accident, accident factor, monitoring of technical state

O. Vovk, Dr. Sc. Sciences., Prof.,ORCID 0000-0002-7531-9847 S. Zaychenko, Dr. Sc. Sciences., Prof.,ORCID 0000-0002-8446-5408

Ye. Chvertko, Cand.Sc. (Eng.), Assoc. Prof., M. Shevchenko, Cand.Sc. (Eng.), Assoc. Prof., A. Pirumov, Cand.Sc. (Eng.), Assoc. Prof.,

O. Radetskaya, Msc

ANALYSIS OF ACCIDENTS ON THE MAIN PIPELINES FOR THE PERIOD 2005-2015.

Main pipelines are widely used for transporting of liquid products on long distances. Unfortunately pipeline operating is related to a number of factors - technological, technical, subjective - which may cause accidents which, in turn, lead to pollution of wide territories, property damage and even casualties. The paper gives analysis of accidents on main pipelines in Ukraine and USA during the period of $2005-2015$. It was determined that accidents often appear to be a result of negative processes in pipeline material during the structure operation, such as corrosion, ageing, mechanical loads and overloads, for example due to ground shifting. Also accidents tend to happen on pipelines which were not properly controlled and inspected. In addition, both Ukraine and USA have a number of old pipelines - those which estimated operation time has already finished. As a main conclusion it should be mentioned that up-to-date methods and means of monitoring of technical state of pipelines are essential for development and application.

Key words: main pipeline, accident, accident factor, monitoring of technical state

\section{References}

1. Law of Ukraine "Pipeline Transport” No 192/96 [electronic resource]: adopted by Verhovna Rada of Ukraine on 15.05.1996 with changes from 28.12.2015. - Kyiv. - Reference: http://zakon2.rada.gov.ua/laws/show/192/96-вр.

2. The State Emergency Service of Ukraine [electronic resource]. - 2016. - reference: http://www.dsns.gov.ua.

3. Proceedings of the national Stock Company "Naftogaz Ukrayiny” " About the Situation With Technogenic and Ecological Safety in Ukraine in 2016”

4. List of pipeline accidents in the United States in the 21 st century [Електронний pecypc] // Wikipedia. 2017. - Режим доступу до ресурсу: https://en.wikipedia.org/wiki/List_of_pipeline_accidents_in_the_United_States_in_the_21st_century\#2005.

5. Papadakis G. A. Review of transmission pipeline accidents involving hazardous substances / G. A. Papadakis. // European Communities. - 1999. - c. 64.

6. Paul W. Parfomak DOT’s Federal Pipeline Safety Program: Background and Key Issues for Congress / Paul W. Parfomak. // Congressional Research Service. - 2016. - с. 32.

7. Smart 'pigs' that sniff out trouble down the pipe [Електронний ресурс] // GE Reports. - 2014. - Режим доступу до ресурсу: https://gereports.ca/smart-pigs-that-sniff-out-trouble-down-the-pipe/\#.

8. A. Pirumov, M. Shevchenko, A. Minakov, S. Minakov, Ye. Chvertko Application of Reverse Magnetization Method of Evaluating Stresses in Welded Structures / Journal of Materials Science and Technology (Bulgary) 2015, Vol. 23, No. 4, pp. 295-302. 